\title{
Japanese science law could bring control as well as cash
}

Tokyo. A new law was passed by the Diet, Japan's parliament, last week, designed to ensure adequate funding of public sector research by making such funding a legal responsibility of the government. The law requires a five-year basic plan for science and technology to be drawn up, and the government will have to report its progress annually to the Diet. It also urges the government to promote increased contact with researchers in other countries.

The Basic Science and Technology Law had been proposed by Omi Koji of the Liberal Democratic Party (LDP), the coalition government's largest party. Koji is a former official at the Ministry of International Trade and Industry (MITI) and one of a group of LDP members who have been pushing for increased support for science and technology (see Nature 378, 8; 1995).

The law has been welcomed by officials at MITI and the Science and Technology Agency (STA). But some scientists fear that it could lead to more direct control of academic research by the government. Similar concern, expressed at the time by the Science and Technology Council - Japan's leading science advisory body, made up of representatives from government, academic institutions and industry - helped to defeat a similar bill in 1968, although it was also opposed by the Ministry of Finance.

The new law does not specify the precise level at which the government should fund science. But Koji expects that it will lead to increased funding for science in the 1996 budget across all government agencies and

\section{Geologist 'victimized' for role in fraud case}

New Delhi. A reader in the geology department of the Panjab University in Chandigarh, India, who helped to initiate charges of scientific misconduct against his boss, the geologist Vishwa Jit Gupta, six years ago, claimed last week that he is being victimized by the university. Its senate has blocked a promotion for which he had been recommended by a selection committee.

Arun Ahluwalia says that his promotion was the only one to be blocked by the senate out of 29 approved by the committee. "If this is the reward for exposing frauds in order to preserve scientific values, then only God can save this country," says Ahluwalia, who, together with the Australian geologist John Talent and others, exposed what is widely referred to as the 'Himalayan fossil fraud' perpetrated by Gupta, a senior professor in the geology department at Chandigarh (see Nature 338, 613; 1989).

Last year, a commission of inquiry found ministries. He claims that the Japanese government, unlike some of its competitors, such as the United States and Germany, contributes a relatively small proportion of national spending on research and development, and that this should be increased for the sake of the economy.

Atsushi Kawashima, the director general for general affairs at MITI's Agency of Industry, Science and Technology (AIST), says the law is expected to raise the awareness of Japanese legislators of the importance of science and technology. He believes that funding increases will be specified in the basic science plan which the government is now required to draft.

Reaction to the law in the academic community has reflected a combination of support and wariness. Itaru Watanabe, for example, professor emeritus at Keio University, says that while the law is likely to benefit industry-oriented research, this may be at the expense of basic research. Junjiro Kanamuri, president of Osaka University, welcomes the new legislation, but emphasizes that academics need to be consulted in drafting of the basic science plan.

Akita Arima, former president of Tokyo University and current president of the Institute of Physical and Chemical Research (RIKEN), is pleased with the new law's implied promise of increased funding, as well as the greater 'internationalization' of Japanese science. But, like Watanabe, he hopes that funding will not be restricted to areas with commercial applications.

Stephen Barker

Gupta alone - and not his co-workers guilty of misconduct. But the university senate, which many claim is dominated by political allies and friends of Gupta, handed down what many consider a relatively mild punishment - namely that he should no longer be permitted to teach graduate students or take any administrative responsibility in the university (see Nature 371, 368; 1994), while targeting Ahluwalia, the only one of several co-workers who had continued the fight against Gupta.

Last week's decision by the university senate to block his promotion is seen by Ahluwalia as a sign of a corroding value system and "a failure of the Indian scientific community to uphold the cause of scientific integrity". He also says he feels let down by the international scientific community for not applying pressure on either the Indian government, or Panjab University itself.

K. S. Jayaraman

\section{European Commission seeks clearer goals for space research}

Munich. Edith Cresson, the European Union (EU) commissioner for science, last week claimed that Europe lacks a long-term political vision in space research, despite the economic and scientific importance of space activities

Speaking at the European Space Forum, a meeting of policy-makers and space technologists organized jointly by the European Commission and the European Parliament, Cresson criticized the lack of coordination of programmes that make use of such activities within the commission.

Space had appeared to be so unimportant to the commission "that it hadn't dreamt of having a director in charge of the section or having a budget for coordination [of space utilization programmes]," she said.

Cresson claimed that national space agencies, as well as the European Space Agency (ESA), have promoted the development of cutting-edge technologies, but that European industry continues to lag behind that of the United States and Japan, particularly in the use of satellite data.

The commission had built up its own programmes in the use of satellite technologies, particularly in telecommunications, navigation and Earth observation. But Cresson argued that these needed to be better coordinated in order to create new markets.

In response to pressure from the European Parliament, concerned at its own lack of direct control of European space policy as this has historically been in the hands of ESA, an intergovernmental body, Cresson is now preparing a report to be presented both to the parliament and to the council of ministers next spring.

The report is being drawn up jointly with Martin Bangemann, the commissioner for industry and telecommunications, and will analyse the commission's programmes involving the use of satellite data and suggest how they might be developed.

Alain Pompidou, a French member of the European Parliament, has already suggested that the commission should set up a task force to develop and promote an EU space policy. This would not be intended to replace ESA, he says, "but it would focus its efforts on specific policy goals, such as meeting users' demands".

Cresson's announcement that the report on promoting the use of space-based data will be ready by the spring is seen as overoptimistic within the commission, as work on the document has barely started. But its conclusions will be closely watched outside Brussels - in particular at ESA - as they could signify a new step in the commission's efforts to exert a greater influence over Europe's space activities. Alison Abbott 